\title{
Incorporation of Food Materials as a Source of Dietary Fibres and Natural Antioxidants in Meat Products and their Effect on Product Quality and Human Health: A Mini Review
}

\author{
Abdul Haque, Saghir Ahmad and Irfan Khan
}

Department of Post Harvest Engineering and Technology, Aligarh Muslim University, Aligarh, 202002, India

\begin{abstract}
Meat and meat products share an important status among the various food products because of their high biological value with the goodness of nutritional compounds. Meat is a perfect source of protein along with minerals, vitamins, amino acids, essential fatty acids and many other specific nutrients. Socio-economic factors have to lead to a change in lifestyle, which in turn has increased the demand for ready to eat products, among which meat products are also rapidly gaining attraction of consumers. Although these meat products have good nutritional value, they generally contain a large amount of fat and added salts but are lack of dietary fibre which leads to various health problems in human consuming meat and meat products. Lack of dietary fibre in meat products gives birth to coronary heart diseases, diabetes, high blood pressure and intestinal cancer etc. Consumers are growing their consciousness towards the health aspect without compromising on nutritional benefits. Therefore, meat products fortified with significant levels of dietary fibre has been suggested. 28-36 g/day dietary fibre is recommended and which can be met by their incorporation in the diet of people consuming meat and meat products. The insoluble part of dietary fibre helps in regulation of intestinal function whereas soluble dietary fibre regarded as helpful in lowering cholesterol level by absorbing glucose in the intestine. Another critical problem concerning meat and meat products is the lipid oxidation which reduces the shelf life of product during storage. Natural antioxidants are suggested for retarding lipid oxidation and ultimately enhancing the shelf life of the product under storage. Synthetic antioxidants are losing publicity because they have revealed several toxicological effects during various studies. Thus there is a growing trend of use of natural antioxidants along with the dietary fibre obtained from plant sources in meat and meat products. Various food wastes such as fruit and vegetable byproducts from food processing industries can serve the purpose of dietary fibre as well as natural antioxidants because of the polyphenolic compounds present in them. Generally, these by-products from fruit and vegetable processing industries are cheap, and their utilisation develops indirect income generation. The utilisation of vegetable and fruit wastes as a source of dietary fibre and natural antioxidants also reduces pollution to some extent which might be caused by their disposal. Thus along with waste reduction, cost reduction in economic terms, it also helps the environment by decreasing the load of their disposal. The incorporation of these by-products from various plant sources attracts consumers as they improve quality attributes viz. physicochemical, microbiological and organoleptic properties in meat and its products with health benefits and hence gives satisfaction to the consumers regarding their health consciousness.
\end{abstract}

Keywords: Meat products, agricultural waste, value addition, health.

\section{INTRODUCTION}

Meat is one of the essential parts of the human diet. Undoubtedly, meat has the richness of protein among the foods having a high degree of bioavailability in comparison to other food products [1, 2]. Meat also contains a good amount of omega- 3 fatty acid, iron and high level of cobalamin [3]. But the negative impact associated with meat and processed meat products is due to lack of dietary fibre. When the meat is regularly consumed may result in various problems related to health like high blood pressure, coronary heart diseases, obesity and cardiovascular disorders [4-6]. By certain scientific evidence, it has been confirmed that specific components in food may also lead to neurological disorders [7]. This problem can be overcome by incorporation of dietary fibre in meat products which modifies textural characteristics, gives

*Address correspondence to this author at the Department of Post Harvest Engineering and Technology, Aligarh Muslim University, Aligarh, 202002, India; Tel: +91-9412601092; E-mail: alsaghirqadri@gmail.com stability to fat, improves emulsification and also improves shelf life $[8,9]$. Another problem that prevails in meat products is the lipid oxidation, and lipid oxidation causes rancidity which affects the quality of product and deteriorates shelf life and also gives undesirable effects which even sometimes forms toxic substances [10]. Antioxidants are used for retarding rancidity, and there are two types of antioxidants, namely synthetic and natural antioxidants. Synthetic antioxidants like tert-butylhydroquinone (TBHQ), butylated hydroxytoluene (BHT) and butylated hydroxyanisole (BHA) are used to put a check on microbial growth which ultimately extends the shelf life of meat and meat products. Potential toxicological effects of synthetic antioxidants have put them under the scrutiny [11]. Nowadays, food processing industries are growing rapidly, which produces a lot of byproducts and waste after producing desired products like apple pomace, cabbage waste, cauliflower-stem waste, grape seed powder, carrot pomace and pineapple pomace etc. which go waste and are usually disposed off after some treatment to save the 
environment which further adds up to the cost. These by-products have potential to serve as dietary fibre and natural antioxidants in meat products which when utilised remove the extra cost addition. The trend of incorporation of vegetable and fruit wastes as a source of dietary fibre and phytochemical compounds providing health benefit is growing among the consumers [12]. Fruit and vegetable contain a significant amount of dietary fibre, and phytochemicals such as polyphenol, a carotenoid with high biological properties and antioxidant activity. Polyphenols show antioxidant, anticarcinogenic properties along with immunity regulator and anti-bacterial activity [13]. Dietary fibre-rich substances are widespread in the food market, but generally, their antioxidant perspective is neglected [14]. But now, the concept of dietary fibre providing also the antioxidant activity is becoming popular [15]. The main focus of attraction towards the dietary fibre with antioxidant activity is due to the combined effect of both dietary fibre and a natural antioxidant in the single fruit and vegetable by-product which is the demand of time. One gram of dietary fibre should provide the free radical scavenging behaviour equivalent to $50 \mathrm{mg}$ Vitamin $\mathrm{E}$ and $50 \%$ dry matter in dietary fibre content from the natural dietary fibre source obtained from by-products [15]. These plant byproducts possessing the virtuousness of dietary fibre as well as antioxidants have shown the evidence of decreased risk of chronic diseases like diabetes (type2 ), cardiovascular diseases and colon cancer [16]. This is because of the capacity of free radical scavenging and antioxidant activities which ultimately gives protection from diseases. Besides health benefits, dietary fibre provides the bulk and prevent the cooking loss in meat, enhances water-binding abilities, thus also providing economic benefits to the producer [17]. In this review, the available literature is examined to reveal the action of dietary fibre and antioxidants obtained from fruit and vegetable waste, in meat and meat products; and their potential application in meat and meat products to provide health benefits along with economy generation and waste prevention.

\section{PLANT-DERIVED DIETARY FIBRES WITH ANTIOXIDANT ACTIVITY}

Codex Alimentarius Commission (CAC) recognises that the dietary fibre (D.F) has increasingly taken up by the consumers as material from the plant sources having advantages associated with health [18]. CAC defines the fibre as carbohydrate-polymers with three monomer units or more that are not digested, and are also not absorbed in the small intestine. Dietary fibres are the residues of plants and carbohydrates which are not absorbed and hence are indigestible [19].

The dietary fibre can be classified into two main categories as:

1. Edible carbohydrate-polymer which occurs in the food naturally.

2. Carbohydrate-polymer that are derived from food raw material by physical means.

However, the most general classification is based on its solubility, which is represented in Figure $\mathbf{1}$. Dietary fibres which are soluble in water are known as soluble dietary fibre, whereas which are insoluble in water are regarded as non-soluble nutritional fibre [20]. Soluble dietary fibre involves pectin, beta-glucan, inulin, psyllium, polydextrose, fructooligosaccharides etc. whereas, on the other hand, cellulose, hemicelluloses, starches, lignin comes under the category of insoluble dietary fibre. Soluble dietary fibre, for example, barley, oats; reduces the risk of cardiovascular diseases, gives protection against diseases related to heart as well as some types of cancers, it also reduces total cholesterol and LDL [21].



Figure 1: Dietary Fiber Classification based on solubility. 
Table 1: Dietary Fibres and their Effect on Health

\begin{tabular}{|c|c|c|}
\hline $\begin{array}{l}\text { Different sources from which dietary } \\
\text { fibres are obtained }\end{array}$ & Effect on Health & References \\
\hline Psyllium husk & Decreases the risk of C.V diseases, help in weight management & [23] \\
\hline Whole grain & Reduce the risk of cholesterol & [24] \\
\hline Guar gum & Lowers systolic Blood Pressure & [25] \\
\hline Seaweed extract & Reduction in plasma cholesterol and glucose level & [26] \\
\hline Barley Flakes & Maintaining blood glucose level and weight control & [27] \\
\hline Chicory & $\begin{array}{l}\text { Reduce the risk of coronary heart diseases, } \\
\text { Inhibition of platelet aggregation, } \\
\text { Protection of endothelial tissue }\end{array}$ & [28] \\
\hline Corn and wheat & $\begin{array}{l}\text { Lowers Blood lipid, } \\
\text { Attenuated blood glucose response }\end{array}$ & [29] \\
\hline Jerusalem artichokes, sugar beet & $\begin{array}{l}\text { Stimulate the growth of non-pathogenic intestinal microflora, } \\
\text { Enhances the immune system }\end{array}$ & [30] \\
\hline Resistant starch & $\begin{array}{l}\text { Aids in laxation, } \\
\text { Improve gut health, } \\
\text { Attenuates blood glucose when substituted for digestible carbohydrates }\end{array}$ & [29] \\
\hline Sugar cane juice & Prevention of cardiometabolic diseases and cancer & [31] \\
\hline
\end{tabular}

Insoluble dietary fibre, for example, obtained from wheat bran, lowers the risk of colon cancer as well as breast cancer, obesity and gastrointestinal diseases [22]. Some dietary fibre derived from different sources along with their effects on human health are given in Table 1.

Isolation of dietary fibre from various sources of plants has diversity in processing certain properties like viscosity, gel-forming property, water binding capacity, which affect the quality of the product [20]. Fruits and vegetables in the dehydrated form can be used in the formulation of food to attain the excellency in quality [32]. Dietary fibre obtained from fruits and vegetables can exchange cation through phytic acid and bind positively charged ions like cadmium, copper, zinc, calcium [33]. Bioactive plant compounds that are not nutrients but are linked with reduced chances of some chronic diseases are known as dietary phytochemicals [34]. When these phytochemicals are regularly consumed in food, they even can protect from certain cancers and CV diseases [35].

\section{FORTIFICATION OF DIETARY FIBRES IN MEAT PRODUCTS}

World's total meat production was estimated at 330 million tonnes in 2017, an increase of 1\% from 2016 [36]. Whereas total meat production in India was found at 7.4 million tonnes in 2017 , which is $2.24 \%$ of total meat production in the world [37]. World bovine meat output rose to 70.8 million tonnes in 2017 , an increase of $1.5 \%$ from 2016 . World buffalo meat production in 2016 was 3.79 million tonnes which increased to 3.83 million tones in 2017 [36]. It is encouraging to see that India is the largest producer of buffalo meat at present. In 2017, the total buffalo meat production in India was 1.63 million tonnes [36]; and it was 1.61 million tones in 2016. Thus this increasing trend in buffalo meat production is suggesting the crackdown on illegal meat establishment have not disrupted the supply channel of buffalo meat. There has an overall increase of $15 \%$ in buffalo meat production in India from 2007 - 2017 as compared to $15.31 \%$ in the world [36]. India has exported 1.2 million tonnes of buffalo meat to the world of worth Rs. 25168.31 crores during the year 2018-19 [38]. India is the largest exporter of buffalo meat and third-largest exporter of meat after Brazil and Australia. India accounts for about $58 \%$ of the world buffalo population and $14.7 \%$ of cattle population. Major export destinations during 2018-19 were Vietnam, Malaysia, Indonesia, Iraq, and Myanmar [38]. The major states for buffalo meat production in India are Uttar Pradesh, Andhra Pradesh, Maharashtra and Punjab [38]. This indicates that the meat industry is gaining momentum day by day, especially in terms of buffalo meat. Recently the Indian situation is changing in favour of processed meat products, especially in metropolitan cities. Due to changing lifestyle, several traditional 
meat products like meat Kabab, Chicken Biryani, Tandoori Chicken have gained marketing; other meat products like Meat Momos, Meat Samosa, Meat Kofta, Meat Steak and Meat Pickle, Meat Patties and Sausages etc. have been able to create an impact on urban consumer and civilian societies. Western-type meat products like cured ham, bacon, sausages, frankfurters, meat burger, luncheon meat/loaves, liver paste etc. are becoming popular in big cities of India too.

Meat consumption also represents some risk to human health due to cholesterol such as obesity, diabetes and cardiovascular diseases [39]. Consumers are seeking low-fat meat products for obtaining diets with health benefits, which has contributed to the formulation of new products of meat to substitute the fat in the classically formulated meat products [40]. So, there is an increase in the demand for functional food, and it is raising the concern towards the high degree of fat used in the meat products. The rancidity in the products of meat develops because of oxidation of lipids while processing as well as storage. Oxidation of lipid is accounted for not only primary oxidation products development but also the development of secondary oxidation products. Oxidation of lipid also reduces the nutritional quality of the meat products along with alteration in flavour, which can cause health risks and losses in economic terms because of poor quality products [41]. For this reason, there is an increase in concern regarding the inclusion of natural sources of antioxidants and dietary fibre in processed meat products due to the safety issues, consumer's acceptance and good application in expanding and improving shelf life of the products. In meat food products, the incorporation of antioxidants is done to prevent oxidative rancidity. Unsaturated fatty acids available in phospholipids are the main domain towards the attack of oxidative rancidity [42]. Oxidation of lipid plays roles in deteriorating the quality and overall acceptability of products. Lipid oxidation badly influences textural properties and nutritional attributes. This process may even produce substances which are toxic like oxide of cholesterol and monoaldehyde, lowering of nutritional attributes is marked due to decomposition occurring in essential fatty acids and lipid-soluble vitamin's antioxidant [43]. Natural antioxidants in meat products can replace several synthetic antioxidants. These natural antioxidants, when added to food, enhance their shelf life by putting a check on the oxidation of lipid, protein and other pigments and improves the quality attributes in terms of textural and sensory quality. Some of the meat products incorporated with fruits and vegetable residues are presented in Table 2 along with their results showing an effect on the quality of meat products.

Table 2: Natural Antioxidants with their Effect on Lipid Oxidation in Meat Products

\begin{tabular}{|c|c|c|}
\hline $\begin{array}{l}\text { Antioxidants from different } \\
\text { sources }\end{array}$ & Effect on meat products /Result & References \\
\hline Guava powder & $\begin{array}{c}\text { Cooked nuggets prepared from sheep meat incorporated with guava powder } \\
\text { showed } 40 \% \text { less TBAR numbers }\end{array}$ & [44] \\
\hline Pomegranate fruit juice solution & $\begin{array}{l}\text { Hen breast meat sample dipped in } 0.02 \% \text { fruit juice phenolic solution reduced } \\
\text { protein oxidation }\end{array}$ & [45] \\
\hline Raw capsicum, radish and carrot & $\begin{array}{l}\text { The vegetable incorporated comminuted mutton products were found superior in } \\
\text { sensory quality }\end{array}$ & [47] \\
\hline Litchi pericarp extract & $\begin{array}{l}\text { Litchi pericarp extract (1.5\%) significantly raised the phenolic content in sheep } \\
\text { nugget and inhibited the lipid oxidation similar to BHT ( } 100 \text { ppm over } 12 \text { days) }\end{array}$ & [48] \\
\hline Rind powder extract & $\begin{array}{l}\text { Rind powder extract significantly inhibited }(p<0.01) \text { oxidation of lipid in cooked } \\
\text { (chicken) patties }\end{array}$ & [49] \\
\hline Extract of chia seed & Lipid oxidation reduced in fresh pork sausage during storage & [51] \\
\hline Sage extract & $\begin{array}{l}\text { Sage extract incorporated to meatball showed a high antioxidant capacity due to } \\
\text { phenolic compound; } 47 \mathrm{mg} \text { gallic acid per } 100 \text { gram }\end{array}$ & [52] \\
\hline Rosemary lyophilised extract & $\begin{array}{l}\text { Rosemary lyophilised extract showed strong antioxidant capacity and inhibited } \\
\qquad 48.29 \% \text { lipid oxidation in a chicken burger }\end{array}$ & [53] \\
\hline
\end{tabular}




\section{DIETARY FIBER AND HUMAN HEALTH}

Consumption of diet enriched with fibre tends to reduce the chance of obesity, coronary heart diseases and even some types of cancers. Dietary fibre provides bulking effect by reducing the energy density of the food. Over a past few years, a trend is going on researching to take advantage of dietary fibre especially their incorporation in the diet which is poorer in fibre because when the dietary fibres are incorporated, they impart such effects which are beneficial to health. Three major benefits that have been counted since the last five decades are: dietary fibre works as a laxative, lowers blood cholesterol level and also provide certain antioxidants. Not all dietary fibres are capable of doing each mentioned action or to the same limit.

\subsection{Impact of Dietary Fibres on Blood Lipid Profile}

Dietary fibre serves the purpose of reducing agent of hyperlipidemia and hypercholesterolemia due to which dietary fibre is regarded as a nutraceutical agent against CV diseases [54]. However, the mechanism exactly responsible for lowering the serum cholesterol level is not very clear. Soluble fibre lowered both total and LDL cholesterol significantly in the complete dose range. Even, diets high in fibre reduced $\mathrm{HDL}$ cholesterol significantly but by much less [55]. Insoluble liquid fibre portion of the Citrus Sinensis derived from its peel showed that serum triglyceride levels could be significantly reduced along with the reduction in complete serum cholesterol, gross liver lipids and cholesterol of the liver [56]. Few important mechanisms are lipoprotein production inhibition as well as cholesterol synthesis inhibition, increase in insulin sensitivity occurring because of delay in absorption of macronutrients and formation of the membrane around the droplets by dietary fibre through which lipase activity is prevented [57]. Hence dietary fibre plays an important role in reducing the chances of cardiovascular diseases.

\subsection{Dietary Fibres and their Role in Disease Prevention}

It is generally known that increased fibre intake leads to lower transit times, improved stool bulk and water concentration [58]. Out of the fibres that are usually consumed in the diet, cellulose tends to produce a greater volume of stool bulk which decreases the transit time [59]. It has been reported that dietary fibre absorbs several toxins present in food or compounds having potential towards mutagens by reducing the colonic exposure to these components $[60,61,62]$. In brief, dietary fibre limits mucosal exposure to a large number of harmful colon substances by decreasing the transit time, diluting these agents and binding them. It also results in acidification which decreases $\mathrm{pH}$ prevailing in the colon, thus inhibiting the growth of harmful bacteria and on the other hand, helps in the growth of lactic acid microflora [63]. It is very difficult to relate the dietary fibre, especially with colon cancer, because of their complex nature. However, the significance of dietary fibre in preventing colon cancer has been described in a quite well manner. There are two ways through which anticarcinogenic activity can be realised, one is the reduction in carcinogenic compound production in the colon [64], and another one is increasing the faecal bulk which reduces the interaction of cancer risk agent occurring in faeces with intestinal mucosa [65]. Regular intake of dietary fibre also helps in lowering the risk of certain types of cancers, particularly colorectal cancer that occurs inside the large intestine by promoting fermentation that produces short-chain fatty acids [66].

\subsubsection{Prevention of Overweight and Obesity}

Dietary fibre can increase the prevalence of Bacteriodetes and Actinobacteria, that are mainly present in lithe ones, and reduce the promotion of Proteobacteria, that is dominant in people suffering from obesity [70]. Dietary fibre also raises hormones of the gut, which plays a role in satiety control and gastric emptying [71].Various researchers have examined the dietary fibre with its potentiality towards weight management [66]. A reduction in the secretion of insulin may be marked by the dietary fibre's action of using fat depots from the human body. The nutrients absorbed at a slower rate because of slowing down the action in gastric emptying occurring due to the intake of a fibre-enriched diet [72].

\subsubsection{Prevention of Type-2 Diabetes Mellitus}

Diets high in whole grain and dietary fibre will protect against diabetes and pre-diabetic conditions by promoting satiety and loss of weight. However, in a meta-analysis, a statistically significant decrease was observed in the risk related to type-2 diabetes, with the significant benefits coming from cereal fibres [67]. The decrease in the concentration of plasma glucose may occur because of the use of products having a high amount of fibre. The dietary fibre has the capacity of lowering glucose peak, which creates a decrease in demand for insulin and prevents the high exhaustion of 
pancreas. The ingested fibre reduces gastric emptying by the formation of a matrix associated with gel [68]. The composition of a gel matrix helps in thickening the contents of the intestine and decreasing the contact between digestive enzyme and food [69]. Moreover, the fibre could change the contractile movements in the gastrointestinal tract and hence reduce glucose transportation to the absorptive surface.

\section{CONCLUSION}

Certain food wastes in the form of by-products obtained from vegetable and fruit processing plants fulfil the criteria of dietary fibre with the goodness of natural antioxidants. They bring certain benefits together. They can be successfully incorporated in meat products which will not only provide health benefits through dietary fibre but also support the enhancement and improvement in meat products' shelf life during storage through the action of natural antioxidants present in them. Thus the overall achievement of quality in meat products can be achieved by incorporation of these by-products. The utilisation of fruit and vegetable wastes may provide environmental and economic benefits at the same time. The sources of dietary fibre and antioxidants reviewed here are not sufficient and need further studies with better methods to make excellent use of plant materials rich in antioxidants and dietary fibre.

\section{ACKNOWLEDGEMENTS}

The authors are thankful to the D/o Post-Harvest Engineering and Technology, Aligarh Muslim University for providing the cordial and healthy environment for a better understanding of concepts.

\section{CONFLICT OF INTEREST}

The authors declare no conflict of interest.

\section{REFERENCES}

[1] Chan W. Macronutrients in meat. In: Jensen WK, Devine M, Dikeman M, editors. Encyclopaedia of Meat Sciences. Oxford: Elsevier 2004; 614-8.

https://doi.org/10.1016/B0-12-464970-X/00235-X

[2] Biesalski HK. Meat as a component of a healthy diet - are there any risks or benefits if meat is avoided in the diet? Meat Science 2005; 70(Pt 3): 509-24. https://doi.org/10.1016/j.meatsci.2004.07.017

[3] Bender AE. Meat and meat products in human nutrition in developing countries. FAO Nutrition Paper 1992; 53: 1-91.

[4] Larsson SC, Wolk A. Meat consumption and risk of colorectal cancer: a meta-analysis of prospective studies. International Journal of Cancer 2006; 11: 2657-74. https://doi.org/10.1002/ijc.22170
Tarrant PV. Some recent advances and future priorities in research for the meat industry. J Meat Science 1998; 49:116.

https://doi.org/10.1016/S0309-1740(98)90035-3

[6] Voskuil DW, Kampman E, Grubben MJ, Goldbohm RA, Brant HA, Vasel HFA. Meat consumption and preparation and genetic susceptibility in relation to colorectal adenomas. Cancer Letters 1997; 114: 309-11. https://doi.org/10.1016/S0304-3835(97)04689-2

[7] Ames BN, Shigenanga MK, Hagen TM. Oxidant, antioxidant and the degenerative disease of aging. Proceedings of the National Academy Sciences USA 1993; 90(17): 7915-22. https://doi.org/10.1073/pnas.90.17.7915

[8] Grigelomo MN, Martin BO. Comparison of dietary fibre from by-products of processing fruits and greens and cereals. Lebens. Wiss U Technol 1999; 3: 503-8.

https://doi.org/10.1006/fstl.1999.0587

[9] Cofrades S, Guerra MA, Carballo J, Fernandez MF, Jimenez CF. Plasma protein and soy fibre content effect on bologna sausage properties as influenced by fat level. J Food Sci 2000; 65: 281-7.

https://doi.org/10.1111/j.1365-2621.2000.tb15994.x

[10] Stafanello FS, Cavalheiro CP, Ludtke FL, da Silva MDS, Fries LLM. Effect of addition of the mushroom extract of the sun on pork sausage and evaluation of the oxidative and microbiological stability of the product. Semina Agrarian Sciences 2015; 36: 171-86.

[11] Zhang $\mathrm{H}, \mathrm{Wu} J$, Guo $X$. Effect of antimicrobial and antioxidant activities of spice extracts on raw chicken meat quality. Food Science and Human Wellness 2016; 5: 39-48. https://doi.org/10.1016/j.fshw.2015.11.003

[12] Knekt $P$, Kumpulainen J, Jarvinen R, Rissanen $H$, Heliovaara M, Reunanen A, Hakulinen T, Aromaa A. Flavonoid intake and risk of chronic disease. The American Journal of Clinical Nutrition 2002; 3: 560-8.

https://doi.org/10.1093/ajen/76.3.560

[13] Paszkiewicz M, Budzynska A, Rozalska B, Sadowaska B. The Immunomodulatory role of plant polyphenols. Postepy Higieny i Medycyny Doswiadezalnej 2012; 66: 637-64. https://doi.org/10.5604/17322693.1009908

[14] Zhu K, Huang S, Peng W, Qian H, Zhou H. Effect of ultrafine grinding on hydration and antioxidant properties of wheat bran dietary fibre. Food Research International 2010; 43: 943-8.

https://doi.org/10.1016/j.foodres.2010.01.005

[15] Saura-Calixto F. Antioxidant dietary fibre product, new concept and potential food ingredient. Journal of Agriculture and Food Chemistry 1998; 46: 4303-6. https://doi.org/10.1021/jf9803841

[16] Hu FB, Rimm EB, Stampfer MJ, Ascherio A, Spiegelman D, Willett. Prospective study of major dietary pattern and risk of coronary heart disease in men. The American Journal of Clinical Nutrition 1999; 4: 912-21. https://doi.org/10.1093/ajcn/72.4.912

[17] Grigelomo-Miguel N, Abadias-Seros MI, Martin- Belloso O. Characterization of low-fat high-dietary frankfurters. J. Meat Sci 1999.

https://doi.org/10.1016/S0309-1740(98)00173-9

[18] European Commission, Draft commission directive: amending directive. Available at: http://www.food.gov.uk/ multimedia/pdf/consulation/cwd, 20 May 2008, 90:46.

[19] Prosky L. what is fibre? Current controversies. Trend Food Sci Technology 1999; 10: 271. https://doi.org/10.1016/S0924-2244(99)00059-X

[20] Tungland BC, Meyer D. Non-digestible oligo- and polysaccharides (Dietary fibre), their physiology and role in human health and food. Comprehensive Reviews in Food Science and Food Safety 2002; 1(3): 90-109. https://doi.org/10.1111/j.1541-4337.2002.tb00009.x 
[21] Pins JJ, Kaur H. A review of the effect of barley B-glucan on cardiovascular and diabetic risk. Cereal Food World 2006; $51(1)$. https://doi.org/10.1094/CFW-51-0008

[22] Stevenson L, Phillips S, Walten KOJ, Sullivan KO. Wheat bran: Its comparison and benefits to health. European perspective: International Journal of Food Science and Nutrition 2012; 63(4): 1001-13. https://doi.org/10.3109/09637486.2012.687366

[23] Anderson JW, Pat Baird, Davis RH, Jr Stefanie, Mary Knudtson, Ashraf Korayam, Valerie Waters, and Christine L Williams. Health benefits of dietary fibre. Nutrition Review 2009; 67: 188-205.

https://doi.org/10.1111/j.1753-4887.2009.00189.x

[24] Schatzkin A, Mouw T, Park Y, Subar AF, Kipnis V, Hollenbeck A, Leitzmann MF, Thompson FE. Dietary fibre and whole-grain consumption in relation to colorectal cancer in the NIH-AARP Diet and Health. The American Journal of Clinical Nutrition 2007; 1353-1360. https://doi.org/10.1093/ajcn/85.5.1353

[25] Cicero AFG, Derosa G, Manca M, Bove M, Borghi C, Gaddi AV. Different Effect of Phyllium and guar dietary supplementation on blood pressure control in hypertensive overweight patients: A Six- month, Randomised Clinical Trial. Clin Exp Hypertens 2007; 29: 383-94. https://doi.org/10.1080/10641960701578378

[26] Panlasigui NL, Bello OQ, Dimatangal JM, Dumelod BD. Blood cholesterol and lipid-lowering effect of carrageenan on human volunteers. Asia Pacific J Clinical Nutritional 2003; 12(2): 209-14.

[27] Rendell M, Vanderhoof J, Venn M, Shehan MA, Arnd E, Rao CS, Gill G, Newman RK, Newman CW. Effect of barley breakfast cereal on blood glucose and response in normal and Diabetic Patient. Plants Food for Human Nutrition 2005; 60: 63-67.

https://doi.org/10.1007/s11130-005-5101-8

[28] Carazzone C, Mascherpa D, Gazzani G, Papetti A. Identification of phenolic constituents in red chicory salads (Cichorium intybus) by high-performance liquid chromatography with diode array detection and electrospray ionisation tandem mass spectrometry. Food Chemistry 2013; 138(2-3): 1062-71.

https://doi.org/10.1016/j.foodchem.2012.11.060

[29] Clemens R, Kranz S, Mobley AR, Nickles TA, Raimondi MP, Rodriguez JC, Warshaw H. Filling America's fiber intake gap: summary of a roundtable to probe realistic solutions with a focus on grain-based foods. The Journal of Nutrition 2012; 142(7): S1390-1401.

https://doi.org/10.3945/jn.112.160176

[30] Shridevi V, Sumathi V, Prasad MG, Satish KM. Fructooligosaccharides- type prebiotic A Review. Journal of Pharmacy Research 2014; 8(3): 321-330.

https://doi.org/10.3390/life3020321

[31] Shyam S, Ramdas A, Chang SK. Isomaltulose: Recent evidence for health benefits. Journal of Functional Foods 2018; 48: 173-178. https://doi.org/10.1016/j.jff.2018.07.002

[32] Viuda- Martos M, Ruiz-Navazas $Y$, Fernandez-Lopez J, Perez- Alvarez JA. Effect of orange dietary fibre, Orengo oil and packaging condition on shelf life of bologna sausage. Food Control 2010; 21: 436-43. https://doi.org/10.1016/j.foodcont.2009.07.004

[33] Thibault JF, Lahaye M, Guillan F. Physicochemical properties of food plant cell wall. In: Schweizer TF, Edward CA, editors. Dietary fibre- A Component of Food. Verlag London: Springer 1992; 21-39.

https://doi.org/10.1007/978-1-4471-1928-9 2

[34] Liu RH. Potential energy of phytochemicals in cancer prevention: Mechanism of action. The Journal Nutrition 2004; 134(12): S3479S-85.

https://doi.org/10.1093/in/134.12.3479S
[35] Okarter N, Liu RH. Health benefits of whole grain phytochemicals. Critical Review in Food Science and Nutrition 2010; 50(3): 193-208. https://doi.org/10.1080/10408390802248734

[36] Food and Agricultural Organization. FAO reports on world meat production. Meat Market Review, 2018. www.fao.org

[37] Basic Animal Husbandry and Fisheries Statistics. BAHFS reports on meat production. Annual Report 2016-17, Govt. of India.

[38] Agricultural and processed food products, export development authority. APEDA report on meat export statistics in India 2017-18. https://apeda.gov.in/apedawebsite

[39] Kouvari M, Notara V, Kalogeropoulos N, Panagiotakos DB. Diabetes mellitus associated with processed and unprocessed red meat. International J Food science and Nutrition 2016; 67(7): 1-9. https://doi.org/10.1080/09637486.2016.1197187

[40] Schmiele M, Barretto ACS, Polonio MAR. Dietary fiber as fat substitute in emulsified and cooked meat model system. LWT-Food Science and Technology 2015; 61(1): 105-11. https://doi.org/10.1016/j.Iwt.2014.11.037

[41] Naveena BM, Muthukumar M, Muthulakshmi L, Anjaneyulu ASR, Kondaiah N. Effect of different cooking methods on lipid oxidation and microbial quality of vacuum-packaged emulsion products from chicken. Journal Of Food Processing and Preservation 2014; 38(1): 39-47. https://doi.org/10.1111/j.1745-4549.2012.00740.x

[42] Lima MCO, Fernandez LG, Simionato JI, Oliveira GB, Silva MV. Oxidative stability of goat meat stored under freezing. Green Journal of Agroecology Sustainable Development 2015; 162-168. https://doi.org/10.18378/rvads.v10i2.2792

[43] Legoynie C, Britz TJ, Hoffman IC. Impact of freezing and thawing on the quality of meat. Meat Science 2012; 91: 9398. https://doi.org/10.1016/j.meatsci.2012.01.013

[44] Verma AK, Rajkumar V, Banerjee R, Biswas S, Das AK Guava (Psidium guajava L.) powder as an antioxidant dietary fibre in sheep meat nuggets. Asian Australas J Anim Sci 2013; 26(6): 886-95 https://doi.org/10.5713/ajas.2012.12671

[45] Vaithiyanathan S, Naveena BM, Muthukumar M, Girish PS, Kondaiah N. Effect of dipping in pomegranate (Punica granatum) fruit juice phenolic solution on the shelf life of chicken meat under refrigerated storage $\left(4^{\circ} \mathrm{C}\right)$. Meat Science 2011; 88: 409-14. https://doi.org/10.1016/j.meatsci.2011.01.019

[46] Soquetta MB, Monteiro SS, Boeira CP, Copetti C, Polli VA da Rosa CS, Terra NN. Development and Quality of Ham Pâté with Added Natural Antioxidant Kiwi Fruit (Actinidia deliciosa) Skin. Journal of Nutrition \& Food Sciences 2017; 07(05).

https://doi.org/10.4172/2155-9600.1000624

[47] Mendiratta SK, Shinde AT, Mane BG. Effect of added vegetable (carrot, radish and capsicum) as functional ingredients in mutton nuggets. Journal of Meat Science and Technology 201; 1:71-6.

[48] Das AK, Rajkumar V, Nanda PK, Chauhan P, Pradhan SR, Biswas S. Antioxidant efficacy of Litchi (Litchi Chinensis Sonn.) pericarp extract in sheep meat nuggets. Antioxidants (Basel) 2016; 5(2): 16. https://doi.org/10.3390/antiox5020016

[49] Naveena BM, Sen AR, Vathiyanathan S, Babji Y, Kondaiah $\mathrm{N}$. Comparative efficacy of pomegranate juice, pomegranate rind powder extract and BHT as antioxidants in cooked chicken patties. Meat Sci 2008; 80(4): 1304-8. https://doi.org/10.1016/j.meatsci.2008.06.005

[50] Brannan RG. Effect of grape seed extract on physicochemical properties of ground, salted, chicken thigh 
meat during refrigerated storage at different relative humidity levels. J Food Sci 2008; 73(1): 36-40.

https://doi.org/10.1111/j.1750-3841.2007.00588.x

[51] Scapin G, Schimdt MM, Prestes RD, Ferreira S, Silva AFC, Rosa C. Effect of extract of chia seed (Salvia Hispanica) as an antioxidant as fresh pork sausage. International Food Research Journal 2015; 22: 1195-1202.

[52] Ganther M, Brodowska M, Gorska-Horczyczak E, WojtasikKalinowska L, Najda A, Pogorzetska E, Godziszewska J. Antioxidant effect of sage (Salvia Officinalis L.) extract on turkey meatballs packed in cold modified atmosphere. CyTAJournal of Food 2018; 16(1): 628-36. https://doi.org/10.1080/19476337.2018.1426632

[53] Pereira D, Pinheiro RS, Heldt LFS, Moura CD, Bianchin M, Almeida JDF, Reis ASD, Ribeiro IS, Haminiuk CWI, Carpes ST. Rosemary as natural antioxidant to prevent oxidation in chicken burgers. Food Science and Technology 2017; 37: 17-23.

https://doi.org/10.1590/1678-457x.31816

[54] Fahrenbach MJ, Riccardi BA, Saunders JC, Lourie IN, Heider JG. Comparative effect of guar gum and pectin on human serum cholesterol levels. Circulation 1965; 31:11.

[55] Brown L, Rosner B, Willett WW, Sacks FM. Cholesterollowering effects of dietary fiber: a meta-analysis. Am J Clinical Nutr 1999; 69: 30-42. https://doi.org/10.1093/ajcn/69.1.30

[56] Chau CF, Huang YL, Lin CY. Investigation of the cholesterollowering action of insoluble fibre derived from the peel of Citrus Sinensis L. Cv. Liucheng. Food Chemistry 2004; 87:361-6.

https://doi.org/10.1016/j.foodchem.2003.12.006

[57] Eastwood MA. The physiological effect of dietary fibre. An update. Annual Revision of Nutrition 1992; 12: 19-35. https://doi.org/10.1146/annurev.nu.12.070192.000315

[58] Lewis SJ, Heaton KW. Roughage Revisited: The Effect on Intestinal Function of Inert Plastic particles of Different Sizes and Shape. Dig Dis Sci 1999; 44: 744-8. https://doi.org/10.1023/A:1026613909403

[59] Cummings JH. In: Vahouny GV, Kritchevsky D, editors. Consequences of the metabolism of fiber in the human large intestine-Dietary fibre in health and disease. New York: Plenum Press 1982; pp. 9-22. https://doi.org/10.1007/978-1-4615-6850-6 2

[60] Ferguson LR, Harris PJ. Studies on the role of specific dietary fibres in protection against colorectal cancer. Mutat Res 1996; 350: 173-84. https://doi.org/10.1016/0027-5107(95)00105-0
[61]

Harris PJ, Vallappilakkandy KS, Roberton AM, Triggs CM, Blakeney $A B$, Ferguson LR. Adsorption of a hydrophobic mutagen to cereal brans and cereal bran dietary fibres. Mutat Res 1998; 412: 323-331.

https://doi.org/10.1016/S1383-5718(98)00003-5

[62] Karakaya S, Kavas A. Adsorption of direct-acting and indirect-acting mutagens by various dietary fibers. Int J Food Sci Nutr 1999; 50: 319-23 https://doi.org/10.1080/096374899101049

[63] Rumney C, Rowland IR. Non-digestible oligosaccharides potential anti-cancer agents. BNF Nutritional Bulletin 1965; 20: 194-203. https://doi.org/10.1111/j.1467-3010.1995.tb00605.x

[64] Harris PJ, Ferguson LR. Dietary fiber: its composition and role in protection against cholesterol cancer. Mutation of Research 1993; 290: 97-110. https://doi.org/10.1016/0027-5107(93)90037-G

[65] Sharma A, Yadav BS, Ritika B. Resistant starch: Physiological roles and food application. Food Revision International 2008; 24: 193-234. https://doi.org/10.1080/87559120801926237

[66] Potter JD. Colorectal cancer: molecules and population. Journal of Natural cancer Institute 1992; 91: 916-32. https://doi.org/10.1093/jnci/91.11.916

[67] Mc Rae MP. Dietary fiber intake and type 2 diabetes mellitus: An umbrella review of meta-analyses. J of Chiropractic Medicine 2018; 17(1): 44-53. https://doi.org/10.1016/j.jcm.2017.11.002

[68] Tapsell LC. Diet and metabolic syndrome: where does resistant starch fit in? Journal Association Analas Chemistry International 2004; 87(3): 756-60.

[69] Brennan CS. Dietary fibre: glycemic response and diabetes. Molecular Nutrition Food Research 2005; 49: 560-70. https://doi.org/10.1002/mnfr.200500025

[70] Parkar SG, Stevenson DE, Skinner MA. The potential influence of fruit polyphenols on colonic microflora and human gut health. Int J Food Microbiol 2008; 124: 295-8. https://doi.org/10.1016/j.ijfoodmicro.2008.03.017

[71] Costabile G, Griffo E, Cipriano P, Vetrani C, Vitale M, Mamone G, Rivellese AA, Riccardi G, Giacco R. Subjective satiety and plasma PYY concentration after wholemeal pasta. Appetite 2018; 125: 172-81. https://doi.org/10.1016/j.appet.2018.02.004

[72] Puupponen-Pima R, Aura AM, Oksman-Caldentey KM, Myllarinen P, Sareela M, Mattalia-Sandhom T, Poutanen K. Development of functional ingredients for gut health. Trends in Food Science and Technology 2002; 13: 3-11. https://doi.org/10.1016/S0924-2244(02)00020-1

Received on 16-03-2020

Accepted on $02-05-2020$

Published on 05-06-2020

DOI: https://doi.org/10.6000/1927-520X.2020.09.10

(C) 2020 Haque et al.; Licensee Lifescience Global.

This is an open access article licensed under the terms of the Creative Commons Attribution Non-Commercial License (http://creativecommons.org/licenses/by-nc/3.0/) which permits unrestricted, non-commercial use, distribution and reproduction in any medium, provided the work is properly cited. 